\title{
SEGMENTASI AREA GIGI MENGGUNAKAN FUZZY C- MEANS
}

\author{
Hardian Oktavianto ${ }^{1}$, Izzati Muhimmah ${ }^{2}$, Taufiq Hidayat ${ }^{2}$ \\ ${ }^{1}$ Teknik Informatika,Universitas Muhammadiyah Jember \\ Jl. Karimata 49 Jember \\ hardian.oktavianto@gmail.com \\ ${ }^{2,3}$ Teknik Informatika,Universitas Islam Indonesia \\ Jl. Kaliurang KM 14.5 Sleman Yogyakarta \\ ${ }^{2} e \cdot n \cdot d i r g a h a y u @ g m a i l . c o m$ \\ 3taufighidefti.uii.ac.id
}

\begin{abstract}
Researches with early detection of caries using x-ray topic has been widely developed, generally before doing object detection, the early step is segmentation. Image segmentation is one of the digital image processing steps used to segregate an area or object observed with other areas or objects. Segmentation has an important role as the initial determination of the desired area or object so that it can be continued to the identification stage. FCM (fuzzy c-means) algorithm is one of object segmentation technique or object grouping in the field of digital image processing study. The basic concept of FCM is to determine the centroid and members of each group adaptively, in principle FCM uses a fuzzy grouping model so that a data or element becomes a member of all the clusters that are formed. Segmentation of the dental area using FCM with 4 clusters aims to segment the enamel, dentin, pulp, and backround areas. The result of segmentation using FCM is influenced by the condition of the dataset used. The background area of the entire dataset can be well segmented. FCM is also capable of segmenting the enamel area but in some datasets, the enamel segmentation results are still mixed with other teeth areas. For the dentin and pulp areas, the segmentation result of these two areas is not optimal yet; most of the dentin and or pulp areas are still segmented with the other teeth's area.
\end{abstract}

Keywords - Fuzzy c-means, Image Segmentation, Teeth Segmentation.

\section{PENDAHULUAN}

Penelitian - penelitian dengan tema deteksi dini karies yang menggunakan sumber citra $x$-ray telah banyak dilakukan, beberapa diantaranya adalah Wei Kuang dan Weiping Ye pada 2008 yang menerapkan kernel-modified SVM sebagai classifier dengan segmentasi watershed sebagai metode dalam peningkatan kualitas citra [1]. João Paulo Ribeiro de Oliveira pada 2009 dalam tesisnya yang mendeteksi karies gigi pada citra panoramic dalam 3 tahap utama, penentuan region of interest (ROI) dari keseluruhan visual citra $x$-ray panoramic, pemisahan area per gigi dengan active contour, dan tahap terakhir adalah klasifikasi [2]. Abdolvahab Ehsani Rad et. al. pada 2015 menerapkan median filter dan thresholding sebagai metode peningkatan kualitas citra $x$-ray, kemudian melakukan pemisahan obyek gigi dengan integral projection, dan metode feature map untuk deteksi karies gigi [3]. Ketiga penelitian tersebut mempunyai kesamaan yaitu melakukan segmentasi terlebih dahulu sebelum melakukan deteksi karies gigi.

Segmentasi citra merupakan salah satu tahap pengolahan citra digital yang digunakan untuk melakukan pemisahan area atau obyek yang diamati dengan area atau obyek lainnya [4]. Pada kasus deteksi obyek pada suatu citra, segmentasi mempunyai peran penting sebagai awal penentuan area atau obyek yang diinginkan sehingga dapat dilanjutkan ke tahap identifikasi [5].

Penelitian tentang segmentasi citra medis juga telah banyak dilakukan. Beberapa diantaranya yang berkaitan dan menunjang penelitian ini adalah, penelitian tentang segmentasi tumor hati dari citra CT-Scan yang dilakukan oleh Bing Nan Li pada 2009 [6], segmentasi organ tubuh dengan format citra medis berbeda yaitu cerebral tissue citra MRI, liver tissue dari citra CT-Scan, dan carotid artery dari citra ultrasound, yang juga dilakukan oleh Bing Nan Li pada 2011 [7], dan segmentasi massa dari citra 
mamografi yang dilakukan Anitha pada 2015 [8]. Semua penelitian tersebut menerapkan metode clustering yaitu fuzzy c-means (FCM) untuk melakukan segmentasi obyek pada citra medis dan menghasilkan akurasi yang baik.

Algoritma FCM merupakan salah satu teknik segmentasi obyek atau pengelompokan obyek dalam bidang kajian pengolahan citra digital. Konsep dasar FCM adalah menentukan centroid dan anggota masing - masing kelompok secara adaptif, pada prinsipnya FCM menggunakan model pengelompokan fuzzy sehingga sebuah data atau elemen menjadi anggota dari semua cluster yang terbentuk. Pada bidang pengolahan citra, yang dimaksud dengan data atau elemen adalah masing masing piksel pada sebuah citra. Keanggotaan data dalam suatu cluster ditentukan oleh derajat keanggotaannya, dimana derajat keanggotaan ini bernilai antara 0 hingga 1 , semakin besar atau tinggi derajat keanggotaan sebuah data terhadap sebuah cluster maka semakin tinggi pula kepemilikan data tersebut pada sebuah cluster dan begitu juga sebaliknya [5], [9].

Pada penelitian ini akan dilakukan segmentasi struktur gigi atau segmentasi bagian - bagian gigi sehingga diharapkan dapat membantu para ahli untuk melakukan identifikasi obyek pada tahap selanjutnya, khususnya identifikasi atau deteksi karies secara dini. Segmentasi nantinya bertujuan mendapatkan 4 area atau bagian dari tiap dataset, yaitu area enamel, area dentin, area pulpa, dan area latar belakang (background). Data citra yang digunakan adalah citra $x$-ray gigi berjenis periapical. Tahap pertama adalah melakukan persiapan data atau preprocessing, kemudian dilanjutkan dengan melakukan segmentasi menggunakan FCM, dan yang terakhir adalah melakukan analisa terhadap hasil segmentasi.

\section{TINJAUAN PUSTAKA}

FCM menggunakan suatu fungsi obyektif $\mu_{m n}$ untuk menentukan derajat keanggotaan dari obyek ke-n terhadap cluster ke-m, dalam bidang pengolahan citra digital, obyek ke-n yang dimaksud disini adalah masing - masing piksel pada suatu citra. Cost function dari FCM adalah :

$$
J=\sum_{n=1}^{N} \sum_{m=1}^{C} \mu_{m n}^{l}\left\|i_{n}-v_{m}\right\|^{2}
$$

dimana $l(>1)$ adalah sebuah parameter yang mengendalikan tingkat fuzzy atau bobot eksponen, $c$ adalah jumlah cluster, $\mu_{m n}$ adalah fungsi keanggotan yang didefinisikan seperti pada rumus (2), dan $v_{m}$ adalah pusat cluster seperti pada rumus (3). Fungsi keanggotaan $\mu_{m n}$ dan centroid $v_{m}$ akan diperbarui secara iteratif.

$$
\begin{gathered}
\mu_{m n}=\frac{\left\|i_{n}-v_{m}\right\|^{-2 /(l-1)}}{\sum_{k=1}^{C}\left\|i_{n}-v_{k}\right\|^{-2 /(l-1)}} ; \\
v_{m}=\frac{\sum_{n=1}^{N} \mu_{m n}^{l} i_{n}}{\sum_{n=1}^{N} \mu_{m n}^{l}}
\end{gathered}
$$

Algoritma FCM ini akan optimal ketika piksel piksel yang dekat dengan suatu centroid mempunyai nilai keanggotaan yang tinggi sedangkan piksel piksel yang jauh dengan suatu centroid mempunyai nilai keanggotaan yang rendah.

Salah satu permasalahan dalam implementasi algoritma FCM dalam segmentasi citra digital adalah kurangnya informasi spasial, dimana informasi spasial ini merupakan salah satu karakteristik penting dari suatu gambar yang merepresentasikan korelasi antar piksel tetangga. Pada suatu citra, piksel tetangga cenderung memiliki nilai - nilai fitur yang serupa, selain itu informasi spasial juga menunjukkan probabilitas kepemilikan pada cluster yang sama. Karena noise dan artefak sering mempengaruhi kinerja dan hasil dari segmentasi, hal ini memunculkan ide untuk menggabungkan informasi spasial ke dalam FCM. Keh-Shih Chuang melakukan penelitian dengan mengembangkan algoritma FCM dimana informasi spasial dapat dimasukkan ke dalam fungsi keanggotaan secara langsung menggunakan :

$$
\mu_{m n}^{\prime}=\frac{\mu_{m n}^{p} h_{m n}^{q}}{\sum_{k=1}^{C} \mu_{k n}^{p} h_{k n}^{q}}
$$

Dimana $p$ and $q$ adalah dua parameter yang mengendalikan masing - masing kontribusi dari kedua fungsi, apabila nilai $p=1$ dan nilai $q=0$, maka hasilnya sama saja dengan FCM tanpa menggunakan atau melibatkan informasi spasial. Variabel $h_{m n}$ merupakan informasi spasial yang didefiniskan dengan : 


$$
h_{m n}=\sum_{k \in N_{n}} \mu_{m k}
$$

Dimana $N_{n}$ merupakan local window yang berpusat disekitar piksel n. Kegunaan dari informasi spasial tersebut sama seperti fungsi keanggotaan, fungsi spasial $h_{m n}$ menunjukkan probabilitas bahwa piksel $i_{n}$ menjadi anggota cluster ke-m. Fungsi spasial dari piksel terhadap suatu cluster akan bernilai besar jika sebagian besar piksel tetangga juga berada pada cluster yang sama. Bobot $\mu_{m n}$ dan centroid $v_{m}$ akan diperbarui menggunakan rumus 2 dan 3 [5],[7].

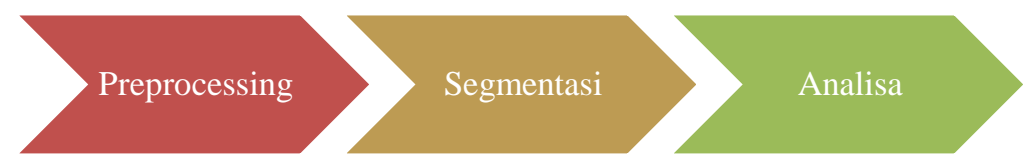

Gambar 1. Tahapan Penelitian

\section{METODE PENELITIAN}

Garis besar penelitian ini terdiri dari beberapa tahapan, yaitu preprocessing, segmentasi dengan FCM, dan yang terakhir adalah analisa hasil. Secara umum tahapan penelitian dapat dilihat pada gambar 1 .

Penelitian ini menggunakan dataset berupa data citra $x$-ray periapical yang berasal dari Pusat Kesehatan Universiti Teknologi Malaysia (UTM) tahun 2013. Masing - masing citra merupakan hasil dari pemeriksaan gigi yang dilakukan terhadap obyek mahasiswa dengan rentang usia antara 25 - 35 tahun. Dataset tersebut diambil dengan menggunakan peralatan medis Sirona buatan Jerman dan proses digitalisasinya menggunakan scanner SIDEX XG [4].

Keseluruhan dataset didigitasi sehingga mempunyai format grayscale dan kompresi JPG, dengan resolusi $512 \times 748$ pixel, beberapa contoh dataset citra dapat dilihat pada gambar 2. Tingkat kecerahan (brightness) dan level kontras untuk keseluruhan citra berbeda beda, pada beberapa citra memuat bingkai batas yang secara visual ditampilkan dengan warna putih, baik bingkai informasi citra yang terdapat pada dasar atau bagian paling bawah citra, atau bingkai batas samping kanan atau kiri. Kondisi dataset tersebut nantinya akan diolah pada tahap praproses.

Tahap preprocessing yaitu melakukan persiapan data citra yang digunakan sebagai masukan (input). Dataset seperti pada gambar 2 kemudian akan dilakukan pemotongan atau cropping untuk pemilihan area 1 buah gigi saja yang mengandung karies, kemudian untuk lebih menyederhanakan proses segmentasi maka dari citra area 1 buah gigi dilakukan lagi pemotongan khusus daerah mahkota gigi (teeth crown) saja. Dataset juga divalidasi oleh ahli untuk mengetahui gigi mana saja yang mengandung karies. Dataset yang telah divalidasi ini kita sebut sebagai citra groundtruth.

Proses cropping dilakukan dengan menggunakan perangkat lunak bantu Matlab. Proses cropping dilakukan dengan memilih area gigi yang mengandung karies, kemudian setelah didapatkan area gigi yang mengandung karies, cropping dilanjutkan dengan memotong area mahkota gigi. Citra hasil preprocessing ditunjukkan seperti pada gambar 3, citra tersebut menjadi masukan bagi proses selanjutnya yaitu segmentasi menggunakan FCM.
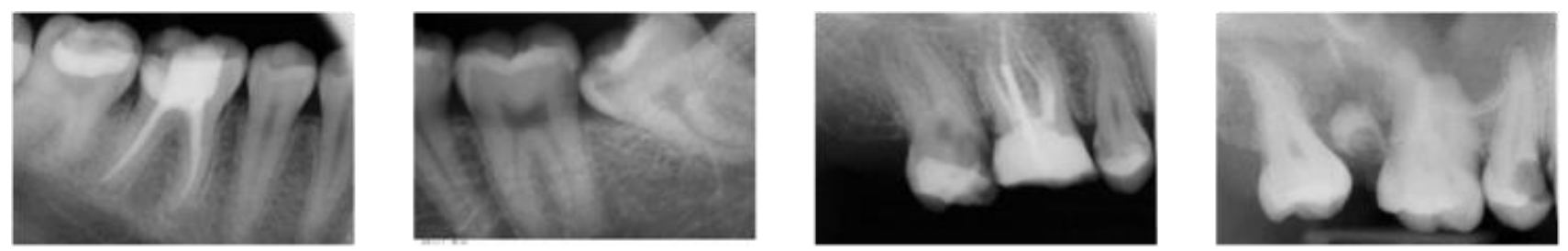

Gambar 2. Contoh Dataset 


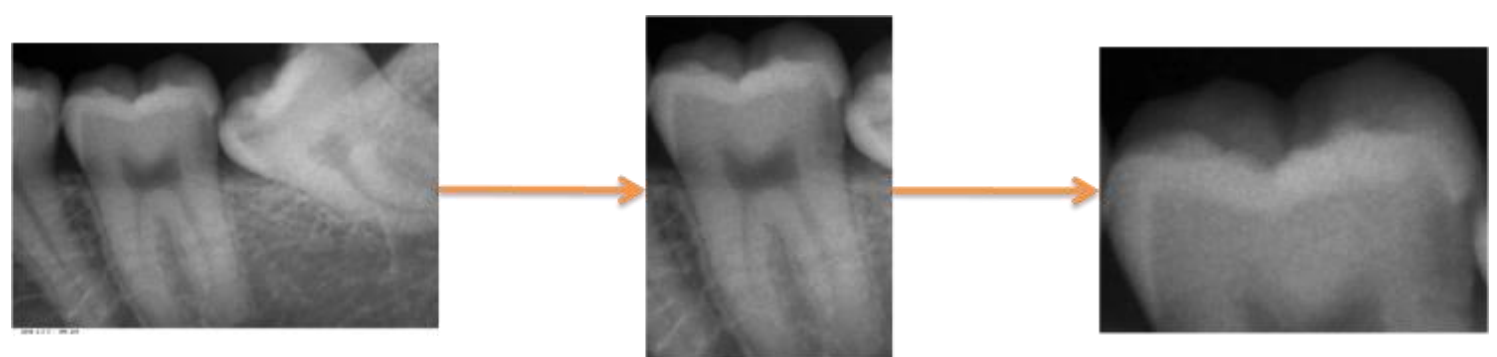

Gambar 3. Hasil Akhir Langkah Preprocess

\section{HASIL DAN PEMBAHASAN}

Dataset yang digunakan sebagai uji segmentasi adalah 10 buah citra yang diperoleh dari 10 citra yang berbeda. Proses cropping dilakukan dengan 2 langkah, pertama yaitu cropping area sebuah gigi yang mengandung karies, kemudian proses selanjutnya yaitu melakukan cropping area mahkota gigi.

Tahapan preprocessing dapat dilihat pada gambar 4. Pada bagian (a) menunjukkan citra groundtruth yaitu citra yang telah divalidasi dan diberi tanda oleh ahli sehingga diketahui gigi mana yang mengandung karies.
Bagian (b) adalah contoh hasil cropping area sebuah gigi. Bagian (c) adalah contoh hasil cropping mahkota gigi.

Hasil akhir dari tahap preprocess ini adalah citra yang menampilkan area mahkota gigi yang mengandung karies seperti yang ditunjukkan oleh gambar 5. Kondisi dataset yang dipakai mengakibatkan proses cropping tidak dapat sempurna memisahkan area gigi yang bersebelahan, sehingga hasil preprocess yaitu hasil cropping area mahkota gigi masih ada yang bercampur dengan sebagian kecil gigi sebelahnya.
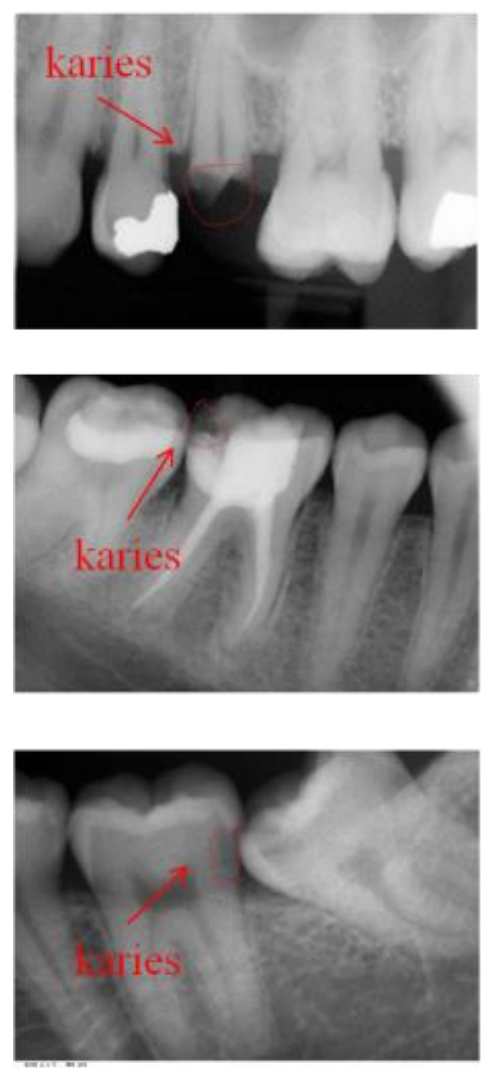

(a)

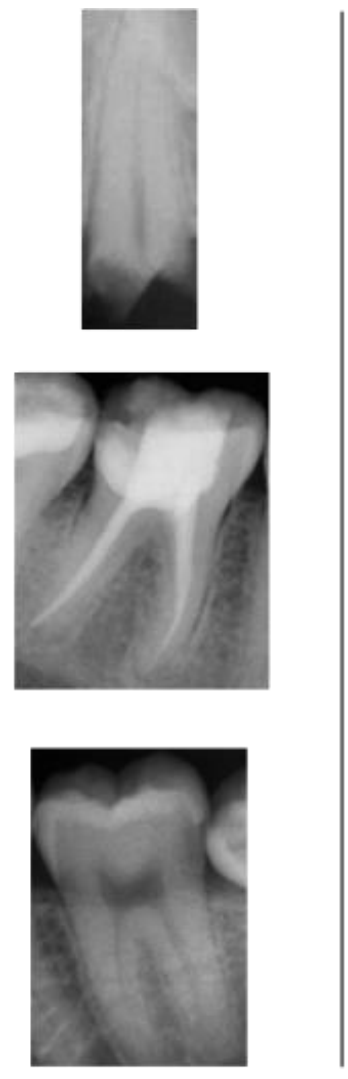

(b)
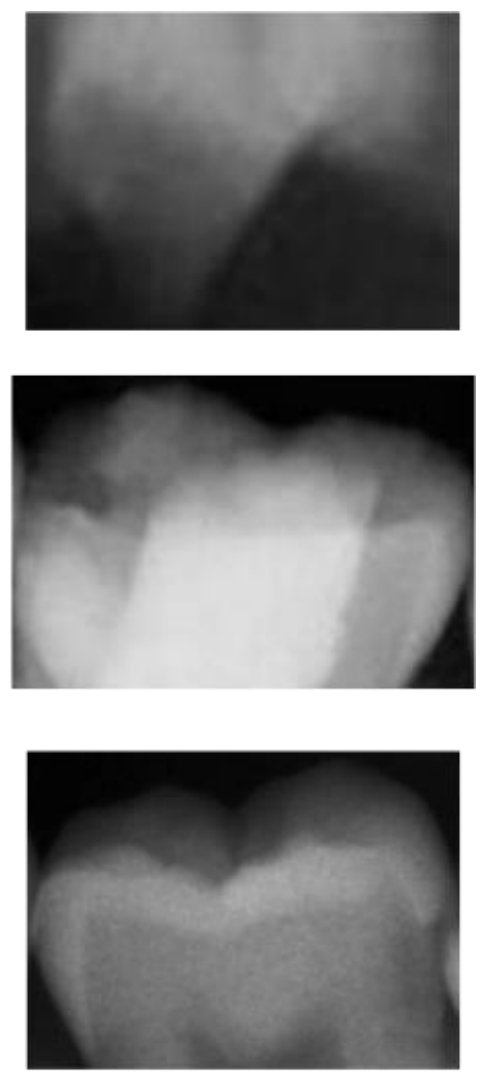

(c)

Gambar 4. Tahapan Preprocessing 

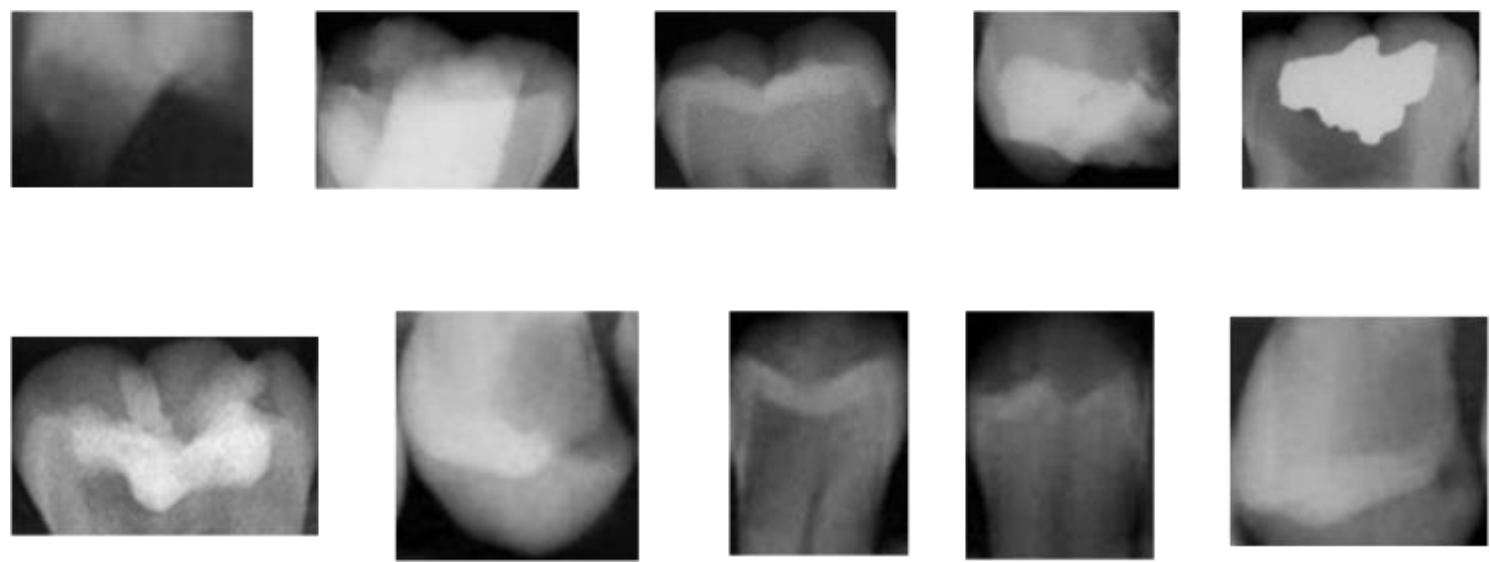

Gambar 5. Hasil Preprocessing

Proses segmentasi dilakukan dengan clustering menggunakan FCM. Proses segmentasi dilakukan pada citra preprocess. Jumlah cluster yang dipilih adalah 4 , yang diharapkan dapat melakukan segmentasi area enamel, dentin, pulpa, dan background.

Enamel yang merupakan bagian terluar gigi adalah struktur gigi yang pertama kali diserang karies, apabila tidak segera ditangani maka karies akan meluas sehingga menginfeksi area dentin, yang merupakan jaringan diantara enamel dengan pulpa, dan akhirnya apabila tidak ditangani maka dapat menembus pulpa, yang merupakan akar gigi yang mengandung saraf dan pembuluh darah. Hasil proses segmentasi menggunakan FCM ditunjukkan pada gambar 6. Area atau wilayah cluster ditunjukkan oleh bagian yang berwarna putih, yang merupakan representasi dari area enamel, dentin, pulpa, dan background.

Secara umum FCM dapat melakukan segmentasi dengan baik, terlihat dari cluster - cluster yang terbentuk. Area background pada masing - masing dataset dapat tersegmen dengan baik, akan tetapi untuk area lainnya yaitu enamel, dentin, dan pulpa, hasil segmentasi tergantung dari kondisi masing - masing citra. Hasil segmentasi untuk enamel juga dapat dihasilkan dengan baik, meskipun pada beberapa citra hasil segmentasi masih bercampur dengan area gigi yang lain seperti yang ditunjukkan oleh lingkaran merah pada gambar 7, sedangkan area dentin dan area pulpa merupakan dua area yang paling sering tidak tersegmen dengan baik, terutama apabila pada mahkota gigi terdapat tambalan.

\section{KESIMPULAN}

Segmentasi area gigi menggunakan FCM dengan 4 buah cluster bertujuan untuk melakukan segmentasi area enamel, dentin, pulpa, dan backround. Hasil segmentasi menggunakan FCM dipengaruhi oleh kondisi dataset yang dipakai. Area background dari keseluruhan dataset dapat tersegmen dengan baik. FCM juga mampu melakukan segmentasi untuk area enamel akan tetapi pada beberapa dataset, hasil segmentasi area enamel masih bercampur dengan area gigi yang lain. Untuk area dentin dan area pulpa, hasil segmentasi kedua area ini belum optimal, sebagian besar area dentin dan atau area pulpa masih tersegmen bercampur dengan area gigi yang lain.

\section{DAFTAR PUSTAKA}

[1] W. Kuang and W. Ye, "A kernel-modified SVM based computer-aided diagnosis system in initial caries," Proc. - 2008 2nd Int. Symp. Intell. Inf. Technol. Appl. IITA 2008, vol. 3, pp. 207-211, 2008.

[2] J. Oliveira and H. Proença, "Caries detection in panoramic dental X-ray images," 2011.

[3] A. E. Rad, I. B. M. Amin, M. S. M. Rahim, and H. Kolivand, "Computer-Aided Dental Caries Detection System from X-Ray Images," in Computational Intelligence in Information Systems, S. Phon-Amnuaisuk and T. W. Au, Eds. Cham: Springer International Publishing, 2015, pp. 233-243.

[4] A. E. Rad, M. S. M. Rahim, A. Rehman, and T. Saba, "Digital Dental X-ray Database for Caries Screening," $3 D$ Res., vol. 7, no. 2, pp. 5-9, 2016.

[5] K.-S. Chuang, H.-L. Tzeng, S. Chen, J. Wu, and T.-J. Chen, "Fuzzy c-means clustering with spatial information for image segmentation," Comput. Med. Imaging Graph., vol. 30, no. 1, pp. 9-15, 2006.

[6] B. N. Li, C. K. Chui, S. H. Ong, and S. Chang, "Integrating FCM and Level Sets for Liver Tumor Segmentation," IFMBE Proc., vol. 23, pp. 202-205, 2009.

[7] B. N. Li, C. K. Chui, S. Chang, and S. H. Ong, "Integrating spatial fuzzy clustering with level set methods for automated medical image segmentation," Comput. Biol. Med., vol. 41, no. 1, pp. 1-10, 2011

[8] J. Anitha, "COMMUNICATION SYSTEM ( ICECS 2015 ) A Spatial Fuzzy based Level Set Method for Mammogram Mass Segmentation," Ieee Spons. 2Nd Int. Conf. Eletronics Commun. Syst. Spons. 2Nd Int. Conf. Eletronics Commun. Syst., no. Icecs, 2015.

[9] W. Cai, S. Chen, and D. Zhang, "Fast and robust fuzzy c-means clustering algorithms incorporating local information for image segmentation," Pattern Recognit., vol. 40, no. 3, pp. 825-838, 2007. 

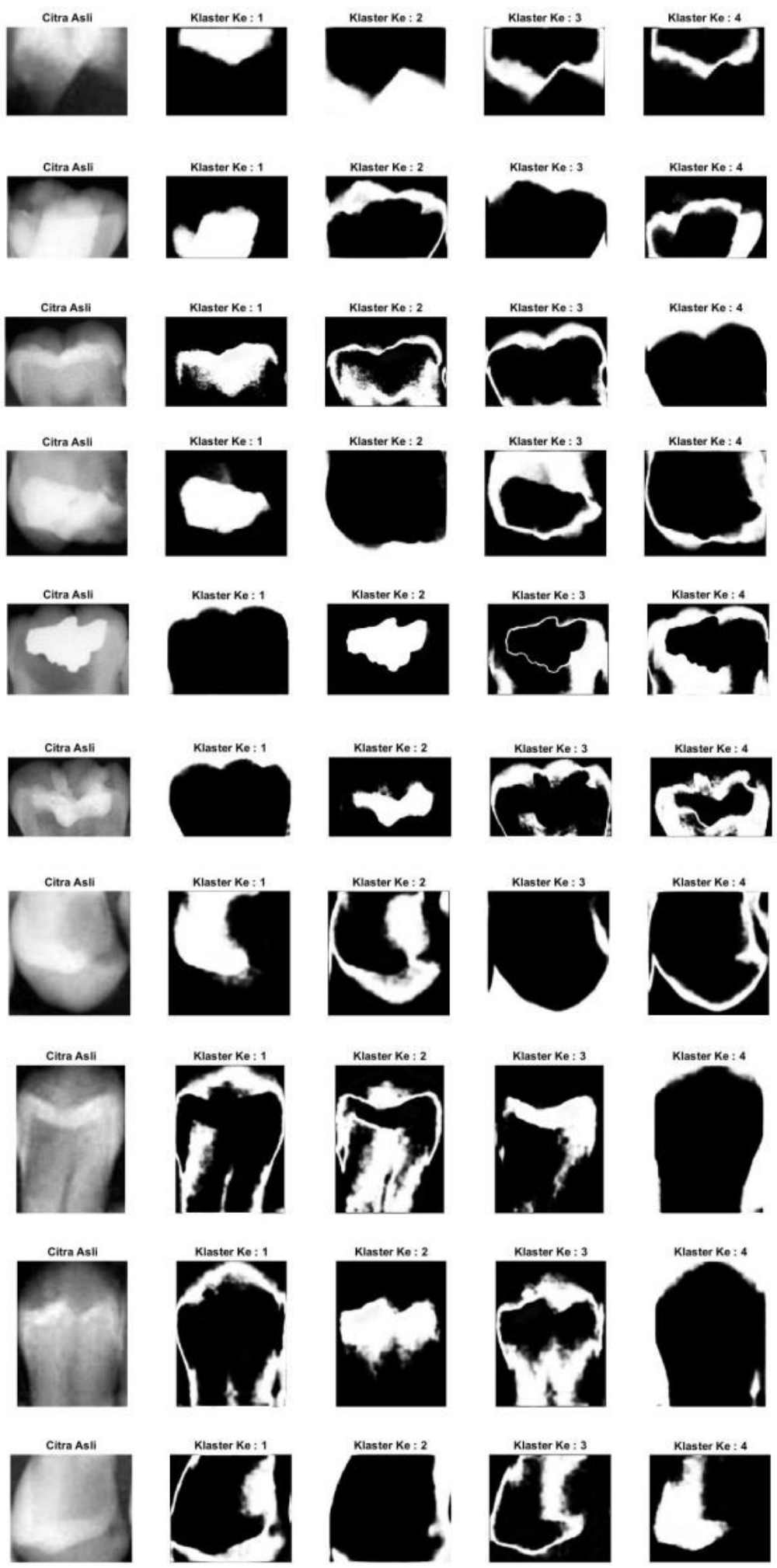

Gambar 6. Hasil Segmentasi 
Jurnal Teknologi Informatika dan Terapan Vol. 04, No 02, Juli - Desember 2017 ISSN: 235-838X
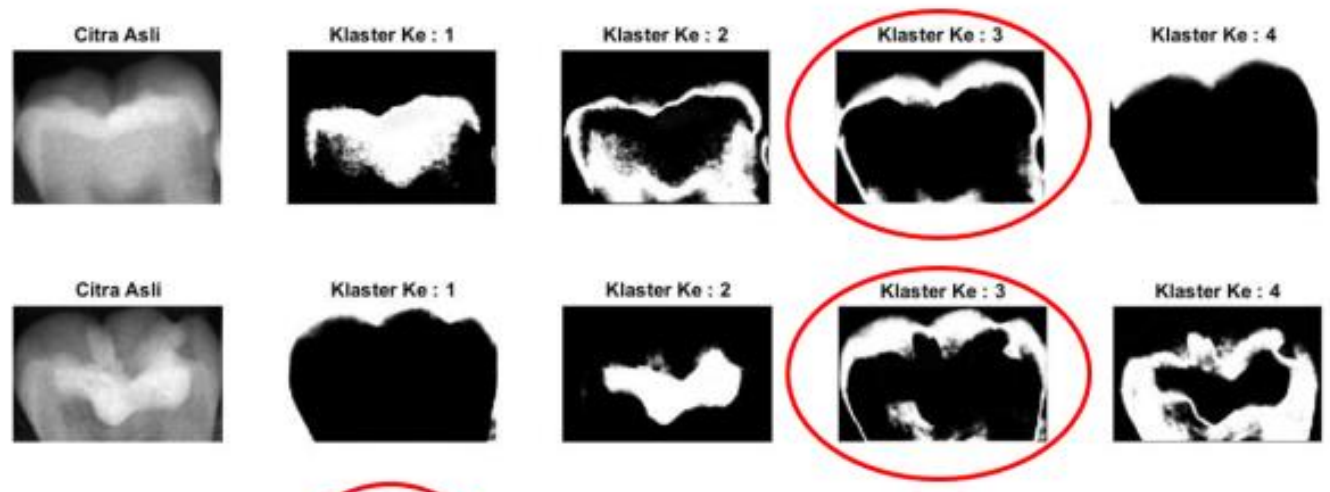

Klaster Ke : 4
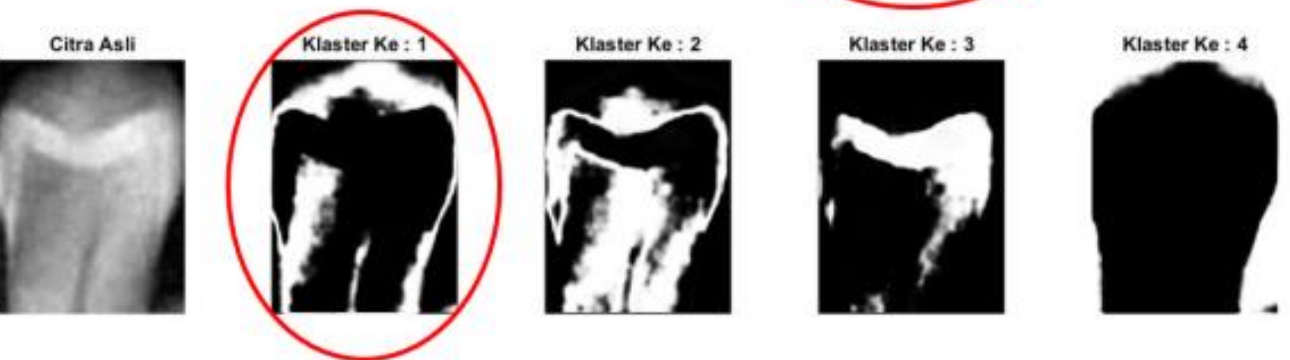

Citra Asli
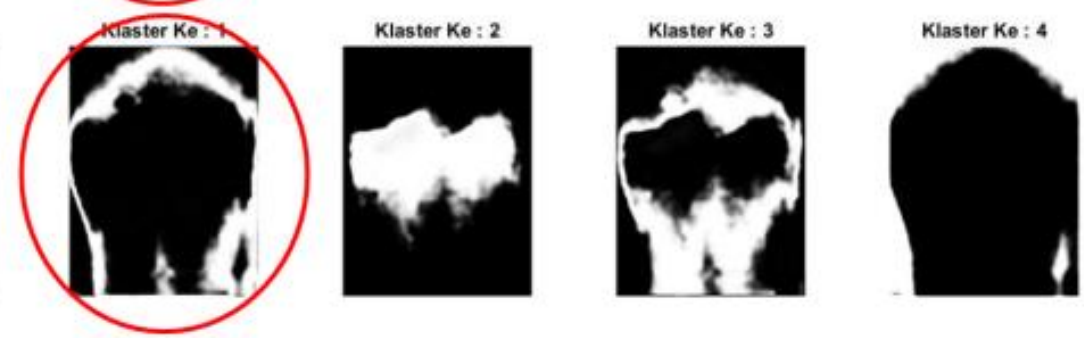

Gambar 7. Hasil Segmentasi Enamel 
$\underline{\text { Segmentasi Area Gigi Menggunakan Fuzzy C-Means }}$ 